\title{
Иноязычные ресурсы современного украинского словообразования
}

\author{
ЕВГЕНИЯ А. КАРПИЛОВСКАЯ \\ Институт украинского языка Национальной академии наук Украины \\ вул. Грушевського, 4, м. Київ, 01001, Україна; вул. Освіти, буд. 3-А, кв. 2, \\ м. Київ, 03037, Україна, karpilovska@gmail.com
}

\begin{abstract}
Članek obravnava problematiko rabe prevzetih prvin v sodobnem ukrajinskem besedotvorju. Narejena je bila analiza novejših ukrajinskih besed, in sicer $\mathrm{v}$ odnosu do poimenovanj istih pojmov $\mathrm{v}$ drugih slovanskih jezikih. Raziskovalno gradivo dokazuje, da je lahko vpliv jezika dajalca, predvsem angleščine kot vodilnega globalizacijskega jezika, ki vpliva na sodobno ukrajinsko besedotvorje, odkrit ali zakrit, primaren ali sekundaren. Funkcijski potencial poimenovanj s tujejezičnimi sredstvi omogoča njihovo presojo komunikacijskega pomena inovacije ter predvidevanje njihove usode $\mathrm{v}$ jeziku prejemniku.
\end{abstract}

The paper discusses the problem of the use of borrowed resources in modern Ukrainian derivation. Analysis of the new Ukrainian words was done in relation to the nominations of the same concepts in other Slavic languages. Material research proves that the influence of donorlanguages, and, above all, English as the leading language of globalization on contemporary Ukrainian derivation, can be explicit vs. hidden, primary vs. secondary. The functional potential of nominations with foreign-language resources enables one to judge about nominative and communicative importance of an innovation and to predict their fate in the recipient-language.

Ključne besede: poimenovanje, besedotvorna sredstva, inovacija, neosemantizem

Key words: nomination, word formation resources, innovation, neosemantyzm

Украина активно включилась в процессы глобализации после распада Советского Союза и провозглашения независимости в 1991 г. В условиях открытого гражданского общества, оживленных экономических, политических, культурных контактов с другими странами для нового украинского 
государства особое значение приобрела проблема сохранения национальной самобытности, в том числе языковой. Украинский язык, получивший статус государственного языка (такой его статус в 1996 г. был закреплен в статье 10 новой Конституции Украины), оказался в сложной ситуации. До 1991 г. он не функционировал полноценно во многих сферах государственного управления, науки, техники и образования. Его заменял тут русский язык как «язык межнационального общения» в бывшем Советском Союзе. В новой независимой Украине украинский язык был призван к удовлетворению всего спектра номинативных и коммуникативных потребностей общества, к обеспечению необходимыми средствами всего разнообразия видов и форм его языковой деятельности.

Перед языковедами была поставлена задача чрезвычайной важности и сложности, в то же время задача, чрезвычайно интересная в профессиональном плане, мобилизующая все их силы и знания. Это - необходимость развития языка, обновления и пополнения его лексикона и грамматики, формирования новых его функционально-стилевых разновидностей, выработки коммуникативных стратегий и тактик, отвечающих духу нового времени, требованиям и вкусам украинского общества в новых условиях его жизнедеятельности. Решение такой задачи тесно связано с проблемой обеспечения гармонического развития национального языка, показателем которого является равновесие между его открытостью к внешнему миру, к процессам глобализации, и сохранением его собственного «лица», в частности, типологических черт национальной номинации. Открытость языка в номинации проявляется в активном использовании иноязычных ресурсов для создания новых наименований (тенденция интернационализации, шире - глобализации), а защита его самобытности предполагает опору на национальные языковые ресурсы в процессах номинации, создание собственных соответствий заимствованиям, активизацию исконных моделей словообразования (тенденция национализации, шире - этнизации, а в украинской культурной традиции - «коренизации») (Лукашанец 2003a, 2003 б, Остапчук 2006, Waszakowa 2009, Карпіловська 2009).

В этой статье мы не стремимся, естественно, к обсуждению нынешней ситуации в украинском литературном языке в полном объеме. Свое внимание сосредоточим лишь на одной проблеме - взаимодействии иноязычных (внешних, заимствованных) и собственных (внутренних, исконных) ресурсов украинской словообразовательной номинации. Выбор в качестве объекта анализа словообразования вполне закономерен, поскольку в украинском, как и в других славянских языках, словообразование по-прежнему является одним из основных способов номинации и средств пополнения лексикона (Земская 2000, Клименко, Карпіловська, Кислюк 2008). Кроме того, многие адаптированные заимствования активно втягиваются далее в процессы словообразования и таким образом дают возможность проследить взаимодействие своих и чужих ресурсов в процессе создания новых наименований (Waszakowa 2003, Карпіловська 2013). 
Свои наблюдения и дальнейшие размышления основываем на материалах компьютерного фонда инноваций (далее - КФИ) в современном украинском языке, созданного в 2006 г. в отделе структурно-математической лингвистики Института языковедения им. А.А. Потебни НАН Украины в Киеве (с 2011 г. этот научный коллектив работает в составе Института украинского языка НАН Украины) и насчитывающего на сегодня свыше 20 тыс. новых слов и словосочетаний, а также на материалах идеографического словаря новой лексики «Активные ресурсы современной украинской номинации» (далее - АРСУН), составленного на основе этого фонда и опубликованного в 2013 г. (Карпіловська et al. 2013). Уже упомянутый КФИ содержит номинации - слова и словосочетания, обнаруженные в текстах современных украинских СМИ (традиционных и онлайновых), в художественной, научно-популярной литературе, публицистике и разнообразной интернет-коммуникации (блоги, чаты, форумы, сетевая почта и реклама и т. п.). Хронологически рубежом для определения новизны того или иного наименования является 1991 г. Кроме того, учитывается характер новизны номинации. Для новых значений уже имеющихся слов (неосемантизмов) наличие фиксации в словарях и текстах до 1991 г. является основанием для определения способа формирования нового значения: повторного заимствования с новым значением, как, например, для слов модератор, трейлер, тендер, рейдер, номінація, прозорий, сірий или же для развития нового значения на украинской языковой почве, как в словах крутий, білий, зелений, майдан, помаранчевий.

На сегодня текстовая база КФИ насчитывает около 20 тыс. микроконтекстов употребления новых номинаций. В формате его параметрической базы данных описаны различные текстовые и системные свойства инноваций: синтагматические (функции в различных типах словосочетаний), парадигматические (синонимические, антонимические, гиперо-гипонимические, омонимические отношения в тексте и в системе языка) и эпидигматические (словообразовательный потенциал). Отмечены также хронология их фиксации в текстах и кодификации в словарях до и после 1991 г., варианты написания, изменения в грамматических свойствах неосемантизмов. Материал для сопоставления с другими славянскими языками черпаем из текстов, национальных корпусов и словарей, в частности, из словарей новой лексики, таких, как «Толковый словарь новых слов и значений русского языка» Л.П. Катлинской (Катлинская 2008), «Новые слова в чешском языке» (Nová slova v češtině 2004), Национальный корпус польського языка (NKJP).

Обсуждая проблему использования иноязычных ресурсов в современной украинской словообразовательной номинации, считаем важным очертить не только спектр таких средств создания новых наименований, но и характер их проявления в языке. Мы имеем в виду различение явных и скрытых заимствований (Markowski 2000, Карпиловская 2009), так называемых семантических калек. При этом, словообразовательные ресурсы мы понимаем как любые средства создания новых номинаций, относя к ним конкретные форманты (аффиксы, корни, основы слов) и модели 
словообразования, образцы построения слов. В такой трактовке ресурсов словообразования опираемся на их определение, предложенное в 1958 г. основателем школы украинской дериватологии И. И. Коваликом в его книге «Учение о словообразовании» (Ковалик 2007: 92).

Современные процессы глобализации способствуют стремительному формированию нового фонда интернационализмов в славянских языках, на что уже неоднократно обращали внимание исследователи. На примере именно этой лексики наиболее выразительны тенденции использования иноязычных ресурсов в словообразовательной номинации отдельных славянских языков, их взаимодействие с национальными ресурсами номинации, общее и различное в современных славянских лексиконах. На целесообразность сосредоточения внимания в сопоставительных исследованиях на лексике специальной, терминологической, обозначающей понятия, реалии, явления, общие для всех славян, указывал в свое время А. В. Исаченко. Размышляя об источниках развития словарных фондов современных славянских языков, он обращал внимание исследователей на то, что наиболее показательными для них в плане определения общего и отличного в инновационных процессах могут быть «именно те лексические элементы, которые непосредственно отражают наиболее активные проявления современной жизни. Такими элементами являются те слова, которые, достаточно условно, можно назвать «терминологическими», а не бытовая лексика с ее специфическим «субстратом» или «адстратом» (Исаченко 1958: 336). Для анализа тенденций использования иноязычных ресурсов в современной украинской номинации и сопоставления украинских инноваций с инновациями в других славянских языках мы и выбрали группы номинаций общих для них понятий. При этом для сопоставления нас интересует не только сам выбор ресурса - национального или иноязычного, а и характер его дальнейшего использования в языке, мера его участия в профилировании такого понятия и сама наявность подобного профилирования как доказательство значимости понятия для сознания носителей языка.

С этой целью в АРСУН мы предложили общий формат для описания функционального потенциала новой номинации как в тексте, так и в системе языка, учитывающего весь спектр свойственных ей синтагматических, парадигматических и эпидигматических отношений с другими, новыми и уже известными, номинациями. Такая матрица служит инструментом для сопоставления с другими языками и формой обобщения языкового материала, а эталоном для сопоставления является материал украинского языка.

В использовании определенного иноязычного ресурса в украинской словообразовательной номинации выделяем несколько способов: 1) явный - а) основы или форманты в составе новых заимствований; б) уже освоенные заимствования с новым значением; 2) скрытый - новое значение уже освоенных иноязычных слов под влиянием новых заимствований (семантическая калька-неосемантизм); 3) использование графических средств языка-источника заимствования для оформления дериватов с гибридной 
структурой. Примером использования такого рода иноязычных ресурсов может быть апостроф после иноязычной основы перед формантом языка-реципиента: $S(s) m s$ 'ка (иные варианты написания этого деривата в украинском языке: смс-ка, есемеска) и ср. этот знак в английском языке перед окончанием формы притяжательного падежа -s: mother's book «книга матери». Как доказывает материал украинского и других славянских языков, иноязычный ресурс словообразования прежде всего составляют заимствованные основы, причем, как новые, осваиваемые на наших глазах, так и уже адаптированные, давно усвоенные.

Несомненно, понятием, общим сегодня для всех славянских языков, стал новый вид связи при помощи специального технического средства - мобильного телефона, т. е. телефона, не имеющего стационарного источника питания и усиления сигнала. В украинском языке номинация мобільний телефон и созданные на ее основе универбы мобільник, мобілка, мобілочка, мобіл, мобіла, мобільчик составляют оппозицию к названиям уже имеющихся технических средств для телефонной связи: стаціонарний, дротовий (провідний), традииійний, справжній, немобільний телефон. Прилагательное мобільний (от французского mobile «подвижный», восходящего к латинскому mobilis «легко двигающийся, скорый») украинскому языку в значении «подвижный, быстрый» известно давно. Первым его в 1955 г. в таком значении зафиксировал «Словарь иностранных слов» под редакцией И.В. Лехина и Ф.М. Петрова (Словник... 1955: 474). В новом же значении «не привязанный к стационарному источнику питания или станции усиления» его зарегистрировала в словаре «Новое в украинской лексике» Д. В. Мазурик (Мазурик 2002: 74) с примерами словосочетаний мобільний зв'язок, мобільний телефон и созданным на основе этого словосочетания универбом мобільник. Прототипом к такому наименованию нового средства связи в украинском и других славянских языках, несомненно, является английская составная номинация mobile phone «переносной, мобильный телефон».

В материалах АРСУН есть номинации с прилагательным-неосемантизмом мобільний как в атрибутивной, так и в субстантивной функции. Такие словосочетания и производные лексемы, нейтральные и экспрессивнооценочные, отражают широкий спектр в современной украинской языковой практике семантических валентностей прилагательного мобільний в его новом значении. Словосочетания «мобільний» бізнес (виклик, гігант, доступ, етикет, життя, зв'язок, Інтернет, номер, оператор, придаток, ринок, розклад, стандарт), мобільна мережа (непокора, реклама, фобія), мобільне голосування, фотополювання и дериваты антимобільний («антимобільні» (правила, пристрої)), немобільний («немобільні» смартфони, немобільний канал (номер, телефон)), замобілена особа очерчивают спектр новых объектов действительности, наделенных таким новым признаком. Дериваты же: простые аффиксальные слова мобільник, мобілка, мобілоч$\kappa a$, мобіл, мобіла, мобільчик и композиты мобіловиробник, мобіловласник, мобіломан, мобіломанія, мобілозалежність, мінімобільний обозначают 1) 
новое устройство для такого вида связи (мобильный телефон), связанных с ним 2) субъектов (производителей, владельцев, любителей и даже тех, кто ворует такие телефоны (ироническое употребление композита мобіломан), 3) состояния субъекта, вызванные использованием мобильного телефона. Кроме того, такие новообразования-прилагательные, как мінімобільний, указывают на недостаточную степень проявления такого признака (АРСУН: 209-210), а рекламные гибридные онимы-названия владельцев мобильных телефонов Мобілич, Мобіленко свидетельствуют о языковой игре с прилагательным-неосемантизмом мобільний с использованием украинских патронимических суффиксов.

Сопоставление с другими славянскими языками доказывает, что они преимущественно для наименования понятия «связь при помощи мобильного телефона» выбирают тот же ресурс - прилагательное, восходящее к латинскому этимону mobilis, cp.: рус. мобильныци телефон (мобильник, мобилка, мобила), белорус. мабільнік, словен. mobilni telefon, болг., македон. мобилен телефон, чеш. mobilek, mobilka, mobilák1 (cp. также в чешском языке mobilní, mobilár̆, mobilák2, mobilofil, mobiloman, mobilomaniak, mobilovat, mobilit (NSČ: 266-268). В то же время при общности вербализуемых понятий заметен выбор разных способов их номинации. Так, украинским композитам мобіловиробник, мобіловласник в доступных нам материалах в иных славянских языках соответствуют составные номинации наподобие рус. владелец мобильного телефона (мобильного), словен. lastnik mobilnega telefona.

Едва ли не единственный среди славянских польский язык предпочтение отдал не иноязычному, а собственному ресурсу номинации, свидетельством чего является семантическая калька komórkowy telefon и образованные на ее основе универб komórka и субстантиват komórkowy. По своей внутренней форме эта номинация соответствует украинскому словосочетанию cmiльниковий телефон (ср. также универбы на его основе стільниця, стільник, стільничка), русскому сотовый телефон (ср. сотовый) и общему для всех этих языков английскому этимону - иному наименованию такого средства связи cellular telephone и композиту на его основе cellphone. Однако такие семантические кальки на основе исконных слов в украинском, как и в русском, языке не обрели активный функциональный потенциал, в частности, словообразовательный. В украинском языке дериваты на основе прилагательного стільниковий остались единичными, как и в русском. Например, в газетном подкорпусе Национального корпуса русского языка нам встретилось слово сотовик, однако лишь как имя собственное-эргоним, наименование информационного агентства, а не сотового телефона либо лица, связанного с ним (НКРЯ).

Иногда для использования той или иной основы в качестве базы для вербализации нового понятия показательно отсутствие вполне прогнозируемой номинации, для которой в языке-реципиенте есть образец. Например, в украинском лексиконе в уже достаточно многочисленном словообразовательном гнезде от прилагательного-неосемантизма мобільний, в отличие 
от чешского языка, нет глаголов. Это требует объяснений, поскольку в украинском языке есть модели для образования глаголов, называющих действия, связанные с передачей сигналов: дзвонити (от дзвін), клаксонити (от клаксон), семафорити (от семафор), телефонувати (от телефон), телетайпувати (от телетайn), телеграфувати (от телеграф). Однако такие глаголы в словообразовательной норме образуют от основ существительных - наименований устройств, средств для передачи сигналов, а не прилагательных, таких, как мобільний. Подобные существительные могут обозначать не только приборы, устройства, но и музыкальные инструменты, но лишь те из них, что принято использовать для подачи сигналов: барабанити (от барабан), трубити (от труба), сурмити (от сурма), трембітати (от трембіта), но не *піанінити (от піаніно) или *скрипкувати (от скрипка). Имеющийся в украинском языке глагол мобілізувати произведен от существительного мобілізація и выражает значение «привести что-либо в активное состояние, призвать на военную службу».

Отсутствие глаголов в новом гнезде от прилагательного мобільний никоим образом не означает, что в украинском языке отсутствуют средства для выражения понятия о таком действии. Украинцы, как и русские или поляки, с этой целью употребляют словосочетания с глаголами, ср.: укр. дзвонити (подзвонити), зв'язатися (зв'язуватися) по мобільному телефону, рус. звонить (позвонить), связаться (связываться) по мобильному телефону, пол. zadzwonić przez komórkę, словен. pokličete na mobilni telefon. Обращает на себя внимание и возрастающая активность в украинской разговорной практике, как и речевой практике других славянских языков, глагола набирати/набрати именно в значении, выражающем действие передачи сигналов при помощи телефона. Академический толковый «Словарь украинского языка» в 11-ти томах еще в 1974 г. зафиксировал его в таком значении относительно стационарного, проводного, телефона: набирати/набрати - 8. Составлять из цифр необходимый для разговора по телефону сигнал (перевод наш. - Е.К). Из приведенных в этом словаре примеров употребления глагола в этом значении выясняем спектр объектов, вовлеченных в такое действие: набирати якийсь номер, набрати на диску телефонного апарата дві изифри «07» (СУМ V: 14). Сегодня в обиходной речи украинцев часто можно услышать: набери мене пізніше, я наберу тебе, коли звільнюся относительно действия именно с помощью мобильного телефона, к тому же, уже даже без уточняющих слов: номер или цицфра. Станет ли такое новое употребление глагола набирати/набрати нормой литературного языка, утратит ли оно пока еще отчетливую разговорносниженную окраску, покажет время. Ясно одно: глаголы со значением передачи сигналов образуются от существительных-названий средств для создания таких сигналов, поэтому они и отсутствуют в гнезде инноваций от прилагательного мобільний в его новом значении.

В отличие от неосемантизма мобільний новая английская аббревиатура $S M S$ в транскрибированной форме есемес в украинском, как и в других славянских языках, стала основой для образования глаголов, обознача- 
ющих как само действие передачи сообщений по мобильному телефону - есемесити, так и однократный способ его выполнения - есемеснути. Вот примеры их употребления в языке украинских средств массовой информации: ...голландијі, які звикли до західноєвропейського комфорту та обслуговування, перетнувши кордон, есемеснули, що «успішно втекли з України» (Ракурс. Рівне, 17.08.2009, № 409); ...вони [зрители - Е. К.] починають встановлювати справедливість $i$ «есемесити», як божевільні.... (Україна молода, 26.07.2011, № 128, интервью музыканта Олега Скрипки). Подобные глаголы фиксируют новые словари и других славянских языков. Например, в словаре «Новые слова в чешском языке» под редакцией О. Мартинцовой в его втором, существенно дополненном издании 2004 г. находим глагол esemeskovat (NSČ: 108). В современных польских текстах функционируют глаголы, производные от неадаптированной английской аббревиатуры (SMS-ować), а также от ее транскрибированного варианта с графическим выделением аббревиатуры-прототипа (eSeMeSować) и без него (esemesować). Показательно, что орфографические польськие словари, например «Большой орфографический словарь» («Wielki słownik ortograficzny») Э. Полянского (Polański 2012) дает как нормативный вариант формы этого глагола esemesować в доказательство освоения английского прототипа.

В использовании иноязычных основ и формантов наблюдаем существенное различие в активности. В справедливости этого наблюдения можно убедиться на примере недавних заимствований в украинском языке. Например, в нем для обозначения средств массовой информации функционируют аббревиатуры 3МI (засоби масової інформащзіі), ЗМІК (засоби масової інформації і комунікації), ЗМК (засоби масової комунікації). Однако отаббревиатурное словообразование в украинском языке предполагает утрату связи исконной аббревиатуры с базовым словосочетанием, ее лексикализацию. Поскольку аббревиатуры $3 M I, 3 M I K, 3 M K$ для носителей украинского языка остаются прозрачными, то словообразование от них ограничивается только такими результатами языковой игры, как ЗМІй (ср. со словом змій), ЗМІст (каламбурное прочтение слова зміст «содержание» как названия лица, связанного со средствами массовой информации, представляющее собой соединение аббревиатуры $3 M I+$ суффикс лица -icm, как в нейтральном деривате машин-іст (машин(а) + -іст).

Для выполнения задачи профилирования понятия, обозначенного аббревиатурами $3 M I, 3 M I K, 3 M K$, более удобной оказалась иноязычная основа медіa-. Она не нова для украинского языка. В «Русско-украинском словаре» Украинской академии наук, изданном под редакцией А. Крымского и С. Ефремова в 1924-1932 гг, уже находим слова с этой основой, восходящей к лат. medium «середина», однако с иными значениями: медіан «средний формат бумаги», медієвізм «увлечение средневековьем», медіо «средний сорт (товара)), медіоваль «типографский шрифт» (СКЄ III: 500). По нашим данным, впервые транслитерированное заимствование в полной (масмедіа) и редуцированной (медіа) формах с дефиницией «средства массовой ин- 
формации (коммуникации) - пресса, кино, ТВ, аудио- и видеокассеты, плакаты и т. п.» в 1999 г. зафиксировала Т. П. Мартиняк в «Русско-украинском словаре иностранных слов» (РУСИС: 178, 180). В начале XXI века украинские словари и тексты фиксируют уже достаточно показательное лексико-словообразовательное гнездо с этой основой. В нем преобладают композиты с производными от некоторых из них, ср.: медіа-акція, медіабомба, медіа-дискурс, медіа-індустрія, медіа-клуб, медіа-компанія, медіамагнат, (и медіа-магнатство), медіа-міст, медіа-олігарх, медіа-партнер, медіа-патронат, медіа-підтримка, медіа-програма, медіа-проект. медіапростір, медіа-технологія, медіа-холдинг, мультимедіа (и мультимедійний $\rightarrow$ мультимедійність). А такие простые аффиксальные производные, как медійний, медійник, медійниия, медї̈ст, доказывают, что для дальнейшего профилирования этого понятия украинский язык использует собственные форманты, адаптируя таким образом иноязычную основу к словообразовательной и грамматической системе украинского языка.

Если украинский язык охотно заимствует иноязычные основы в качестве базы для профилирования понятий, то для создания аспектных инноваций, выражения различных словообразовательных значений предпочитает использовать собственные, национальные форманты. В качестве примера приведем активно обновляемую ныне категорию слов-названий любителей кого-, чего-либо (часто сверх меры). Активизацию образования номинаций лиц, чрезмерно увлеченных чем-либо или кем-либо, с отрицательной оценкой такого превышения меры демонстрируют новые композиты с основой -залежний: алкозалежний, інтернетзалежний, кіберзалежний, наркозалежний, політзалежний, тютюнозалежний и даже мітингозалежний и новинозалежний. Основе -залежний в таком новом значении в названиях лиц синонимичны причастия стурбований, заклопотаний в составных наименованиях лица или групп лиц, ср: національно стурбовані партї, мовно стурбований електорат (иногда и в написании через дефис в сочетании с наречиями (культурно-стурбована особа), політично заклопотаний політик, національно заклопотаний дурник. Субстантивированное причастие заклопотаний в разговорной речи используется для обозначения лица с сексуальными проблемами (ср. с тем же значением русское разговорное озабоченный).

Параллельно с новыми собственными основами-суффиксоидами в украинском лексиконе появились и новые производные с иноязычными формантами: аббросновами -фан (от фанатик) и -голік (от алкоголік), ср.: інтернет-фан, кінофан, юлефан (от имени Юля (Юлія Тимошенко - украинский политик) или інтернетоголік, ватоголік. В этом плане показательно и появление композитов-гибридов с эмоционально-оценочной коннотацией. Например, для обозначения лица, изготавливающего клоны в современном украинском языке есть адаптированный английский композит клонмейкер и его конкурент - клонувальник, суффиксальное производное от глагола клонувати «создавать, изготавливать клоны». Однако для номинации изготовителя плохих, некачественных клонов в украинском языке 
создан композит клонороб с собственной конечной основой -роб (от глагола робити «делать»). Именно в сочетании с иноязычными начальными основами украинская основа -роб приобретает отрицательную оценочную коннотацию, ср.: бракороб «бракодел», віршороб «стихоплет».

Украинский язык усваивает новые иноязычные основы как базу для вербализации новых понятий, однако в дальнейшем их профилировании, он, как убеждают вышеприведенные примеры, опирается на собственные форманты с прозрачной внутренней формой. Это отчетливо проявляется в соотношении дериватов с иноязычными формантами, выражающими определенное значение в общем виде, с дериватами, национальные форманты которых дают возможность формировать разряды слов как с общим (категориальным), так и с частными (разрядными) словообразовательными значениями. Например, заимствованная из английского языка основа -мейкер указывает вообще на изготовителя того, что обозначено начальной основой слова: клонмейкер, іміджмейкер, хітмейкер, кліпмейкер. Украинскую основу -роб с таким же категориальным значением в отличие от ее иноязычного соответствия, способны уточнять основы с разрядными значениями, указывающими на способ изготовления или обработки того, что названо первой основой, совершения над ним действия, такие, как -piz, -дув (склороб и склоріз, склодув), -кур, -черпій (винороб и винокур, виночерпій), -вал (сукнороб и сукновал), -вар (сиророб и сировар) и др. Анализ новых украинских дериватов, в создании которых использованы иноязычные ресурсы словообразования, вселяют надежду на то, что украинскому языку не угрожает превращение его в национальный вариант globish, утрата им самобытности, в частности, национального колорита его словообразовательной номинации. Напротив, глубокая, детальная разработка новых понятий способствует активизации собственных словообразовательных ресурсов национального языка, использованию моделей создания слов, соответствующих принципам национальноязыковой концептуализации и категоризации мира.

\section{ЛИТЕРАТУРА}

Елена ЗЕМСКАЯ, 2000: Активные процессы современного словопроизводства. Русский язык кониа ХХ столетия (1985-1995). Москва: Языки русской культуры. 90-141.

Александр ИСАЧЕНКО, 1958: К вопросу о структурной типологии словарного состава славянских литературных языков. Slavia XXVII/3, 334-352.

Євгенія КАРПІЛОВСЬКА, Лариса КИСЛЮК, Ніна КЛИМЕНКО, Валентина КРИТСЬКА, Тетяна ПУЗДИРЕВА, Юлія РОМАНЮК, 2013: Активні ресурси сучасної української номіначії: Ідеографічний словник нової лексики. Київ: ТОВ «КММ». 
Евгения КАРПИЛОВСКАЯ, 2009: Интернационализация явная и скрытая в современном украинском лексиконе. Przejawy internacjonalizacji w językach stowiańskich. Siedlce: Wydawnictwo Akademii Podlaskiej. 43-52.

Євгенія КАРПІЛОВСЬКА, 2013: Конкурування ресурсів у сучасній слов'янській номінації: своє-засвоєне-засвоюване. Слов'янські обрії 6/1. 245-258.

- -, 2009: Семантико-прагматична диференціація словотворчих ресурсів мови: своє та засвоєне. Новые явления в славянском словообразовании: система и функционирование. Москва: Изд-во Моск. ун-та. 228-244.

Лия КАТЛИНСКАЯ, 2008: Толковый словарь новых слов и значений русского языка. Москва АСТ: Астрель.

Ніна КЛИМЕНКО, Євгенія КАРПІЛОВСЬКА, Лариса КИСЛЮК, 2008: Динамічні прочеси в сучасному украӥнському лексиконі. Київ: Видавничий дім Дмитра Бураго.

Іван КОВАЛИК, 2007: Вчення про словотвір: словотворчі частини слова. Вчення про словотвір: Вибрані праці. Івано-Франківськ-Львів: Місто НВ. 21-169.

Александр ЛУКАШАНЕЦ 2003а: Працесы інтэрнаџыяналізаџыі ў рускай, беларускай і уккаінскай мовах. Słowotwórstwo/Nominacja. Innsbruck: Univer. Innsbruck; Opole: Uniwer. Opolski. 59-77.

- -, 2003б: Тэндэнщьыя да нацыяналізащыі ў рускай, беларускай і уккраінскай мовах. Słowotwórstwo/Nominacja. Innsbruck: Univer. Innsbruck; Opole: Uniwer. Opolski. $137-151$.

Данута МАЗУРИК, 2002: Нове в украйнській лексиці: Словник довідник. Львів: Світ.

Тамара МАРТИНЯК, 1999: Русско-украинский словарь иностранных слов. Харьков: Прапор.

НКРЯ: Национальный корпус русского языка. www.ruscorpora.ru

Оксана ОСТАПЧУК, 2006: Языковое варьирование как фактор внутренней динамики в современном украинском языке: уровни и способы манифестации. Глобализация - этнизация: этнокультурные и этноязыковые процессы. Москва: Наука. Кн.1. 210-238.

Російсько-украӥнський словник / Гол. ред. А. Кримський та С. Єфремов, 1924-1932. Київ: Українська радянська енциклопедія. Т. I-III.

Словник іншомовних слів / Під ред. І. В. Льохіна Ф. М. Петрова, 1955. Київ: Державне видавництво політичної літератури УРСР.

СУМ: Словник української мови, 1970-1980. Київ: Наукова думка. Т. I-XI.

Andrzej MARKOWSKI, 2000: Jawne i ukryte nowsze zapożyczenia leksykalne w mediach. Język w mediach masowych. Warszawa: Upowszechnianie Nauki-Oświata «UN-O». 96-111.

NRJP: Narodowy Korpus Języka Polskiego. www.nkjp.pl

NSČ: Nová slova v češtině: Slovník neologizmů, 2004. Praha: Academia. Vyd. 2.

Krystyna WASZAKOWA, 2009: Internacjonalizacja polskiej leksyki - stan obecny, prognozy na najbliższą przyszłość. Przejawy internacjonalizacji w językach słowiańskich. Siedlce: Wyd. Akademii Podlaskiej. 11-28. 
--, 2003: Przejawy tendencji do internacjonalizacji w systemach słowotwórczych języków zachodniosłowiańskich. Słowotwórstwo/Nominacja. Innsbruck: Univer. Innsbruck; Opole: Uniwer. Opolski. 78-102.

Edward POLAŃSKI, 2012: Wielki stownik ortograficzny. Warszawa: PWN.

\section{TUJEJEZIČNA SREDSTVA SODOBNEGA UKRAJINSKEGA BESEDOTVORJA}

Članek obravnava problematiko rabe prevzetih prvin v sodobnem ukrajinskem besedotvorju. Raziskovalno gradivo dokazuje, da je lahko vpliv jezika dajalca, predvsem angleščine kot vodilnega globalizacijskega jezika, ki vpliva na sodobno ukrajinsko besedotvorje, odkrit ali zakrit, primaren ali sekundaren. Funkcijski potencial tako nastalih poimenovanj s tujejezičnimi sredstvi omogoča njihovo presojo komunikacijskega pomena inovacije ter predvidevanje njihove usode $\mathrm{v}$ jeziku prejemniku.

Predmet analize so prevzete besedotvorne podstave in prevzeta besedotvorna obrazila. Raziskovana je bila njihova vloga pri širjenju kognitivnih in komunikacijskih zmožnosti v sodobni ukrajinščini, kategorizacija in oblikovanje konceptov. Mednarodni značaj teh sredstev ukrajinskega besedotvorja je potrjen s primerjavo poimenovanj $\mathrm{v}$ drugih slovanskih jezikih: v ruščini, poljščini, češčini, bolgarščini, slovenščini itd. Gradivo za tovrstno primerjavo je bilo zbrano v slovarjih novejšega besedja, nacionalnih korpusih slovanskih jezikov in spletni komunikaciji. Prispevek se osredinja na funkcijskost tega gradiva $\mathrm{v}$ ukrajinščini.

Popoln razvoj nacionalnega jezika predvideva sorazmernost med domačimi poimenovalnimi sredstvi in njihovo sposobnostjo asimilacije prevzetih besed, s prilagojenostjo leksikalnemu, slovničnemu, besedotvornemu in morfemskemu sistemu nacionalnega jezika prejemnika. Funkcija prevzetih besedotvornih podstav nakazuje njihovo pomembnost pri poimenovanjih jezika prejemnika, prav tako pa tudi njihovo sistemsko stabilnost. Članek predstavlja tipološko pestrost aktivnih prevzetih besed, in sicer semantične ter besedotvorne kalke, hibride, polkalke. Posebna pozornost je posvečena kognitivni in komunikacijski primernosti izposojenk v odnosu do poimenovanj, temelječih na domačih (ukrajinskih) sredstvih. 